\title{
SHIFTING THE SYSTEM OF INDONESIAN WORD FORMATION: THE STUDY ON MORPHOLOGY AND SOCIOLINGUISTICS OF ACRONYMS, BLENDING, AND CLIPPING
}

\section{PERGESERAN SISTIM PEMBENTUKAN KATA BAHASA INDONESIA: KAJIAN MORFOLOGIS DAN SOSIOLINGUISTIK AKRONIM, BLENDING, DAN KLIPING}

\author{
M. Zaim \\ Fakultas Bahasa dan Seni, Universitas Negeri Padang, Indonesia \\ Jl. Prof. Dr. Hamka, Air Tawar, Padang \\ mzaim unp@yahoo.com; mzaim@fbs.unp.ac.id
}

\begin{abstract}
The general guidelines of Indonesian word formation as annexed in appendix II of the reference standard of the Indonesian Grammar has not yet accommodated the Indonesian word formation system used by the Indonesian speakers today. Meanwhile, a new system of word formation began to emerge and the old paradigm shift in conjunction with the development of science and technology, and the change of social, cultural, and political paradigm. As a result, the reference standard of Indonesian grammar is no longer adequate to understand the system of the formation of the new words. Morphological studies, which analyze the internal structure of the words can be used as a theoretical foundation to address the issues of the Indonesian word formation. From the other side, sociolinguistic studies, which analyze the link of language with the language speakers in the community, can give meaning to the word formation shift. This article discusses (1) the morphological shift of the Indonesian word formation system of acronyms, blending, and clipping, (2) the sociolinguistic functions of the word formation, and (3) the productivity of the word formation system. The study of the shift of word formation system revealed a shift in the way of thinking and the way of looking at social, cultural, and political problems of the Indonesian speakers nowadays.
\end{abstract}

Keywords: word formation, language shift, morphology, sociolinguistics, blending, clipping, acronym

\begin{abstract}
Abstrak
Pedoman umum pembentukan kata Bahasa Indonesia pada Lampiran II Tata Bahasa Baku Bahasa Indonesia belum mengakomodasi sistem pembentukan kata Bahasa Indonesia yang digunakan oleh penutur Indonesia saat ini. Sementara itu, sistem pembentukan kata baru mulai bermunculan menggeser paradigma lama bersamaan
\end{abstract}

(C) Universitas Negeri Padang 248 
dengan perkembangan ilmu pengetahuan dan teknologi, serta perubahan paradigma sosial, budaya, dan politik. Akibatnya, standar acuan tata bahasa Indonesia sudah tidak memadai lagi untuk memahami sistem pembentukan kata baru. Kajian morfologi, yang menganalisa struktur internal kata dapat dijadikan landasan teoritis untuk mengatasi permasalahan pembentukan kata bahasa Indonesia. Dari sisi lain, kajian sosiolinguistik, yang menganalisa hubungan bahasa dengan penutur bahasa di masyarakat, bisa memberi makna pada pergeseran pembentukan kata ini. Artikel ini membahas (1) pergeseran morfologis sistem pembentukan kata dalam bahasa Indonesia pada bentuk akronim, blending, dan kliping, (2) fungsi sosiolinguistik dari pembentukan kata, dan (3) produktivitas sistem pembentukan kata. Kajian tentang pergeseran sistem pembentukan kata mengungkapkan adanya pergeseran cara berpikir dan cara melihat masalah sosial, budaya, dan politik para penutur Bahasa Indonesia saat ini.

Kata kunci: pembentukan kata, pergeseran bahasa, morfologi, sosiolinguistik, blending, kliping, akronim

\section{INTRODUCTION}

Language change cannot be separated from the social changes of a community. Social change arises because of the process of interaction between communities and the process of adaptation through mutual communication they do. For communication to run smoothly, both parties must understand the expressions used by the language users. The process of interaction and adaptation in a language community will affect to the forms of the language used since language is a social phenomenon.

Language is not static but dynamic. Language is always changing, and the change was carried out by the speakers of the language itself to deliver a message. The changes occurred not only because of dissatisfaction with the existing language, but there is a tendency to look for something new and different from the existing words at the time. The group of language users has its creativity in communicating within the group. Government agencies, the private sector, mass media, and the groups of a community have roles in bringing about new terms related to the policies, activities, and things that will be communicated to the recipients. Many new terms appear in a communication process. The language speakers use new terms developed from the old vocabularies they have, and even adopting and adapting from foreign languages.

Word formation is the creation of the new word. It studies under the study of morphology, the study of the smallest meaningful unit of language (Booij, 2007). Combining two or more meaningful language elements will form a new construction with the combined meaning of the two or more existing elements or new meaning apart from the meaning of the elements that make it up. This is the element of language which is called word. When the word is used in communication, it will be influenced by the context of the language use. In sociolinguistics, it is known as registers, the words used in a particular context of speakers and just show up and have meaning in that context (Trudgil, 1992; Trosborg, 1997).

The Indonesian word formation is set in the general guidelines of word formation as annexed in appendix II of the reference standard of Indonesian Grammar (Moeliono, 1988; Alwi, 1998; Pusat Bahasa, 2007). This book describes aspects of grammar terminology that includes the use of basic words, the process of derivation, the process 
of reduplication, and the process of merging. Another book, "Pengindonesiaan Kata dan Ungkapan Asing" only explains how to adopt or adapt foreign words and phrases into Indonesian (Sugono, 2009). Meanwhile, another book that discusses the formation of the word is "Pedoman Umum Ejaan Bahasa Indonesia Yang Disempurnakan" (General Guidelines of the Enhanced Indonesian Spelling) published by Pusat Bahasa (2004), which regulates the way of writing abbreviations and acronyms. Thus, the explanations of the Indonesian word formations are discussed separately in several books published by Pusat Bahasa.

Compared with the theories of the word formation or lexical formation, as suggested by some grammarians (see McManis, 1987; Katamba, 1993; Booij, 2007; Lieber, 2009; Zaim, 2009), the description of the Indonesian word formation has not been adequate yet, especially when viewed from the massive development of the new word formation by Indonesian users nowadays. Therefore a comprehensive assessment of the Indonesian system of word formation based on the use of language by the speakers would be instrumental in understanding the language phenomena.

Booij (2007) states that traditionally word formation consists of two kinds, namely derivation, and compounding. Language users can create or manufacture new words by blending, acronym, clipping, and alphabetisms. McManis (1987) says that there are five types of word formation in various languages, i.e., compounding, affixation, reduplication, internal morpheme change, and suppletion. In English, we can find ten types of word formation, i.e., derivation, compounding, acronyms, backformation, blending, clipping, coinage, functional shift, morphological misanalysis, and proper names. Lieber (2009) uses the term "lexeme formation" for the meaning of word formation. According to Lieber, there are seven types of word formation, i.e., derivation, affixation, compounding, conversion, coinage, blending, and backformation. Among those types of word formation, the three types; acronyms, blending, and clipping are categorized as abbreviation, shortening a word (Kridalaksana, 1983; McManis, 1987; Zaim, 2000).

Of the various forms of word formation system, abbreviation is considered to be the process of new word formation mostly used by users of the language. Almost every day we find a new abbreviation in newspapers, magazines, and other mass media as well as in daily conversation. Abbreviation is the process of shortening a word by deleting one or more parts of words or combining parts of words to create a new form which then is considered to be a new word. Abbreviation aims to produce a shorter form of its original form. In Indonesian, abbreviation can be found in the form of blending, clipping, acronym, contraction, and the symbol of the letter (Sutawijaya, 1996).

Moeliono (1988) and Alwi (1998) divide abbreviation into two types, namely clipping, and acronyms. Clipping is an abbreviation in the form of one or more letters. Clippings can be a person's name, title name, address, job title or rank (eg Muh. Yamin, M.Hum, Bp, Kol.), short form for the official name of government institutions, agencies or organizations, as well as the name of the document (eg DPR, PGRI, KTP), ordinary clippings consisting of three letters or more (eg, $d l l ., d s b$.), chemical symbol, unit of measure, weights, and currency (eg $\mathrm{Cu}, \mathrm{cm}, \mathrm{l}, \mathrm{kg}, \mathrm{Rp}$.). Acronym is an abbreviation in the form of combined initial letters, combined syllable, or a combination of letters and syllables of a series of words that are treated as a word. In terms of formation, there are two types of acronyms, (1) acronym in the form of initial letters of the sequence of words (eg SIM, UNP), (2) acronym in the form of combination of syllables or a 
combination of letters and syllables of a series of words (eg Bappenas, Secata). Moeliono (1988) includes the term of blending into the type of acronym. In Indonesian, there are some requirements in forming acronyms; (1) the number of syllables acronym should not exceed the number of syllables in the Indonesian common word, (2) the acronym is formed by the combination of vowels and consonant harmony in accordance with the usual patterns of Indonesian words (Moeliono, 1988; Alwi, 1998).

Zaim (2000), Zaim (2001), and Zaim (2008) have tried to trace the word formation in the latest Indonesian newspapers news published in Padang. Of new words appeared lately, the form of the acronym and blending very much appear. These forms vary in their appearance, in the sense that some forms are abiding by the existing rules and many of them deviate from the existing rules.

Human beings are not static. Their thinking, choice, and behavior vary according to need and situation; they adapt their language. This adaptation of language according to situation, context and purpose form language variety which is called "register." This term is used under the study of sociolinguistics (Waardhaugh, 1986; Trudgill, 1992; Sumarsono and Partana, 2002). Acronyms, blendings, and clipping can be analyzed based on sociolinguistic function; the role played by a particular form of language within a speech community (Zaim, 2004). The study of the shift of the word formation system may reveal a shift in the way of thinking and the way of looking at social, cultural, and political problems of the Indonesian speakers today.

This research will answer the following research questions: (1) How is the morphological shift of Indonesian word formation system of acronyms, blendings, and clippings? (2) What are the sociolinguistic functions of the word formation?, and (3) How is the productivity of the word formation system based on morphological studies?

\section{METHOD}

This study is descriptive research, which describes the language phenomena as they are used in a speech community (Zaim, 2014). In linguistics, this term is known as descriptive linguistics. It is opposed to prescriptive linguistics, which describes the language as it should be with the specified criteria for particular linguistic events which are considered to be proper and correct language (Sudaryanto, 1993). The object of this study was the Indonesian word formation of acronyms, blendings, and clippings. The research data were sentences in which there were acronyms, blendings, and clippings in them. The sources of research data were written Indonesian of news and articles in the newspapers Kompas, Republika, Media Indonesia, Nova, Aneka, Sport, Pulsa, Tempo, and Intisari. The reason for choosing those newspapers and magazines as the source of data was that the use of Indonesian language on these sources reflected the use of Indonesian currently by its speakers. Thus, the obtained data reflected the use of all types of word formation or linguistic phenomena

The method of data collection used in this research was the observation method (Sudaryanto, 1993). Observation method is a way of obtaining data by observing the use of the language being studied, the spoken language and the written language (Mahsun, 2005; Zaim 2014). The method of data analysis used in this research was distributional method, a method of data analysis which uses the language itself as a determined rule, that is the element of language as the research object (Sudaryanto, 1993). To analyze the productivity of the Indonesian word formation, the researcher 
did the followings. Productivity is divided into four types: very productive, quite productive, less productive, and not productive. The system of word formation is very productive if the process was widespread on eligibility conditions, predictable, and there is no obstacle. The system of word formation is quite productive if the process was typical in many types of situations, somewhat predictable, and sometimes there are obstacles. The system of word formation is less productive if the process only occurs in certain types of conditions with and often challenged. The system of word formation is not productive if the process occurs just in exceptional circumstances, and is very limited.

\section{RESULT AND DISCUSSION}

\section{Result}

1. The morphological shift of the Indonesian word formation system of acronym, blending, and clipping

There are three forms of word formation shift that will be discussed here; they are acronyms, blendings, and clippings.

\section{a. Acronyms}

Acronyms are formed by taking the initial letters (sounds) of each word and uniting them into combination which is itself pronounceable as a separated word, for example, BPK (Badan Pemeriksa Keuangan/Finance Audit Agency), PLIK (Pusat Layanan Internet Kecamatan/sub-district Internet Service Center), and CIBI (Cerdas Istimewa dan Bakat Istimewa/Intelligent privileges and Special Talent). Look at the examples in the following sentences.

(1) BPK melakukan audit investigatif terhadap proyek PLIK (PULSA, 24 April - 7 Mei 2013) (BPK did investigative audit of the PLIK project.)

(2) Mereka akan dibina dalam program yang bernama CIBI. (Republika, 9 April 2013) (They will be trained in a program called $\underline{\text { IBI.) }}$

In general, acronyms are written using capital letters as shown in the examples above. In the process of forming an acronym, the preposition untuk (for), dalam (in), atas (on), and the conjunction dan (and) are often not taken as a part of the acronym. Nevertheless, for specific acronyms, prepositions and conjunctions are included in the acronyms. At the acronym CIBI (Cerdas Istimewa dan Bakat Istimewa/Intelligent Privileges and Special Talent), conjunction dan is not included as the element of the acronym, but in the acronym DAUN (Dana Alokasi untuk Nagari/Allocation Fund for Nagari), and KDRT (Kekerasan dalam Rumah Tangga/home violence), prepositions were included in the acronyms.

Shifting the acronym formation begins when acronym without the use of capital letters was found. All elements of the acronym are made in lowercase. Look the following example.

(3) Produksi minyak sebesar 28 ribu bph. (Republika, 22 Maret 2013)(Oil production was 28 thousand $\underline{b p h}$.

The acronym bph (barel per-hari/barrels per day) in a sentence (3) above is not written with capital letters as it used to be an acronym. 
Acronym was originally written in the form of a unitary form of words that are restricted by space. The next shifting of acronym formation is the discovery of acronyms written as a compound word in the form of two units of words. Look at the following examples.

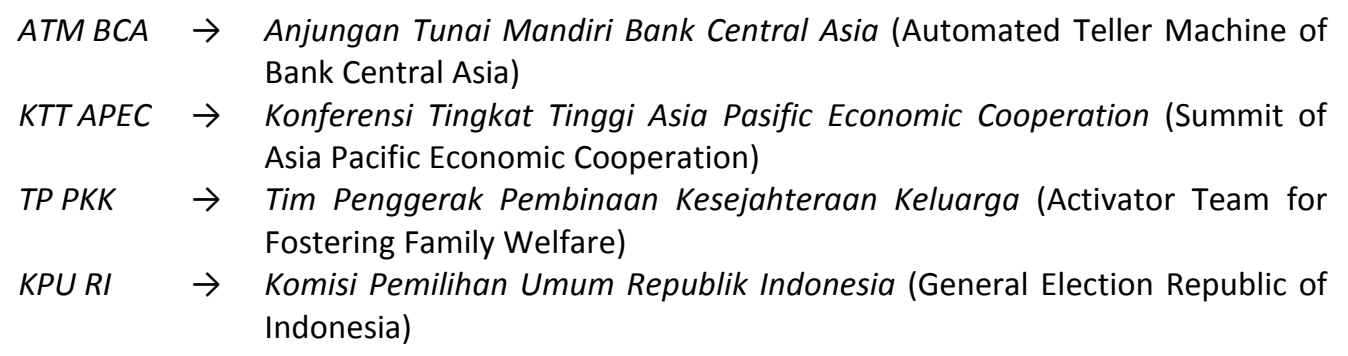

Acronyms are not only a row of initial letters of words but can also contain elements of letters and figures. Look at the following sentence.

(4) Sekarang ada Hers Protex kemasan praktis yang bisa jadi P3K. (NOVA, 17-23 Mei 2013) (Now there is Hers Protex practical packaging that can be $\underline{P 3 K}$.)

The use of figure shows the frequency of the letter appeared in the acronym. This is possible if the initial letters of every word are the same as in the word P3K (Pertolongan Penuh Pada Kebocoran/full relief on the leak) in sentence (4) above. In this acronym, there are three words that begin with the letter $P$, so that the three words, that should be written PPP, are now written as P3. Some acronyms that involve letters and figures can be seen below.
P2TP2A $\rightarrow$ Pusat Pelayanan Terpadu Pemberdayaan Perempuan dan Anak (Integrated service center for empowerment of women and children)
B2SA $\rightarrow \quad$ Beragam Bergizi Seimbang dan Aman (diverse, nutritious, balance and safe)
$\mathrm{MP3EI} \rightarrow$ Master Plan Percepatan dan Perluasan Ekonomi Indonesia (Master plan for acceleration and expansion of Indonesian economy)

The position of figure placement tends to be inconsistent with the acronym. If in the above examples, figures are placed after the letter that repeatedly appears, in the following examples figure is placed before the letter that was repeated.

SM3T $\rightarrow$ Sarjana Mendidik di Daerah Terdepan, Terluar, dan Tertinggal (scholars educate at the forefront, outermost, and left behind region)

The figure 3 on this acronym refers to the letter $T$, not the letter $M$. If we follow the previous rules, the acronym should be SMT3, not SM3T.

The acronyms that appeared lately did not consider the number of letters in the acronyms. Take a look at some of the following acronyms, PP PTHKTI (Pengurus Pusat Pemuda Tani Himpunan Kerukunan Tani Indonesia/Central Board of Youth Farmer Association of Indonesian Farmers Harmony), PT PLN-PJB II (Perseroan Terbatas Perusahaan Listrik Negara Pembangkit Tenaga Listrik Jawa Bali II/Java-Bali Power Station II), and Menneg PM/PBUMN (Menteri Negara Penanaman Modal/Pengelolaan Badan Usaha Milik Negara/State Minister for Investment/ Management of StateOwned Enterprises).

Furthermore, the new phenomenon that arises in constructing the acronym is that the acronym does not always have to write the initial letters of the words, but pronounce one of the letters as they recite the alphabet. For example, ELSAM 
(Lembaga Studi dan Advokasi Masyarakat/Institute for Policy Research and Advocacy) was not written as LSAM. The same phenomenon was also found in the acronym ELTEHA (instead LTH) (Zaim 2001). Another acronym shift is mixing capital letters and small letters in the acronym. This is mainly to avoid the same acronym in the same field. For example, PPn for the acronym of Pajak Pertambahan Nilai (Value Added Tax), while PPnBM for the acronym of Pajak Penjualan Barang Mewah (Sales Tax for Luxury Goods). The next shift occurs by changing one letter in the acronym with the corresponding sound. The shift of this type was found in the establishment of the acronym GAZA (Gabungan Anak jalanan/Association of Street Children) instead of GAJA. The formation of the acronym should be based on the letters contained in the basic word, letter $Z$ is not included in the original word of Gaza and is considered to represent the letter $J$ that should be used in the acronym.

In addition to changing the shape of several rows of words into an acronym, as described above, the acronym of foreign languages (mainly English) are often adopted into a new term and commonly appeared in Indonesian. Look at the following sentences.

(5) Payakumbuh pemenang MDGs Award 2012 (Padang Ekspres, 28 Maret 2013)(Payakumbuh is the winner of MDGs 2012 Award)

(6) Bolpoin ini menyediakan kapasitas simpan $1 \mathrm{~GB}$, dapat menampung 1.000 gambar (Tempo, 11 Februari 2013)(This pen provides a storage capacity of $1 \mathrm{~GB}$, and can accommodate 1,000 images)

(7) Indonesia mesti gunakan APEC; Ekspansi korporasi global ubah paradigm (Kompas 27 Agustus 2013).

(Indonesia should use APEC; global corporate expansion changes paradigm)

In the above sentence, the acronyms MDGs (Millennium Development Goals), GB (Giga Bites), and APEC (Asia Pacific Economic Countries) appear in Indonesian written language through a process of borrowing. Also, there are some acronyms derived from foreign languages that are retained its use, e.g., acronyms Lol (letter of intent), MoU (memorandum of understanding). In the acronym IMF, although there is a term in Indonesian, Dana Moneter Internasional, the IMF acronym is still used to refer to the financial institutions of the world, there is no desire to change it into DMI, as it has been done in the abbreviation of PBB (Perserikatan Bangsa Bangsa) as a substitute of the UN (United Nations).

Based on the above analysis, the shift of the Indonesian word formation of acronyms can be concluded as follows.

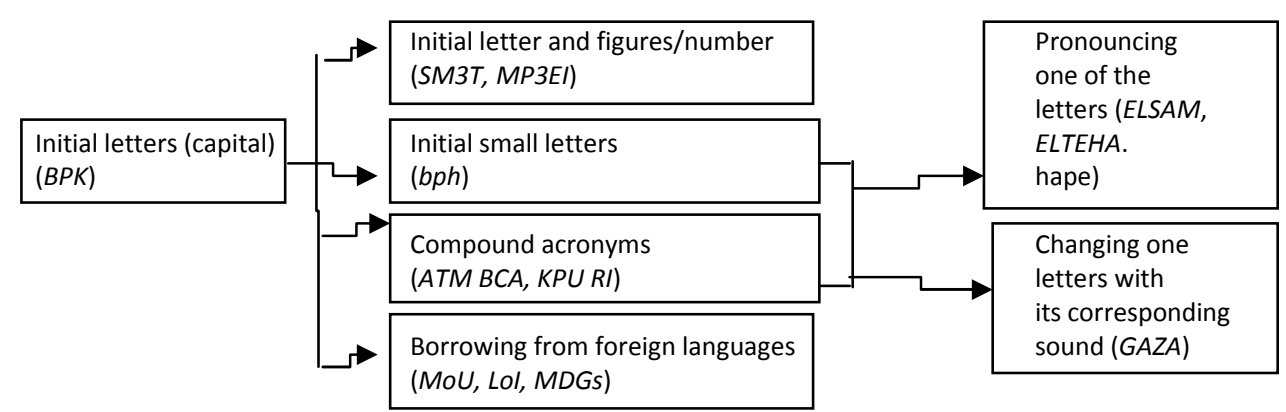

Figure 1: The Shift of the Indonesian Word Formation of Acronym 
Figure 1 above shows that at the beginning, the form of acronym in Indonesian was combining the initial letters of each word, and it only consisted of one word (e.g., Badan Pemeriksa Keuangan was acronymized as BPK). After that there were shifted into six variants, (1) the use of figures to indicate the repetition of the same letters (for example, Sarjana Mendidik di Daerah Terdepan, Terluar, dan Tertinggal which was acronymized as SM3T). Then, the acronyms which were written in small letters (e.g., barel per hari was acronymized as $b p h$ ). After that, compound acronym occurred (e.g., Anjungan Tunai Mandiri Bank Central Asia was acronymized as ATM BCA). Then, in line with the emergence of foreign-language acronym (mainly English) borrowing foreign language acronyms in the Indonesian language were used (e.g., MoU, Lol, MDGs). The next shifting is changing the acronym letter with its pronunciation in one or more letters (for example, ELSAM, ELTEHA, and hape) and replacing one of the acronym letters with its corresponding sound (e.g., GAZA instead of GAJA).

\section{b. Blending}

Blending is a type of Indonesian word formation that is commonly found in mass media in Indonesia. Primarily blending is created by combining two or more parts of words to create a new word. Parts of the words which are connected may be the beginning, middle, and end of the words. Parts of the words which are combined have some variations; combining the beginning parts of each word, the beginning and end parts of words, the beginning and the middle parts of words, the middle and end parts of words, the end parts of each words, and the beginning, middle and the final parts of the words. Almost all combining systems can be obtained, except the combining system involving only the middle parts of the words.

(a) Combining the beginning part of the words, for examples, dugem (dunia gemerlap), balita (bawah lima tahun), tipikor (tindak pidana korupsi)

(b) Combining the beginning and the end part of the words, for examples, miras (minuman keras), senpi (senjata api), ponsel (telepon selular), gaptek (gagap teknologi)

(c) Combining the beginning and the middle part of the words, for examples, disdik (dinas pendidikan), naker (tenaga kerja)

(d) Combining the middle and the end part of the words, for example, curanmor (pencurian kendaraan bermotor)

(e) Combining the end and the end part of the words, for examples: raskin (beras miskin), gakin (keluarga miskin)

These types of blending can be found in various news of mass media as shown in the following sentences.

(8) Selama ini aku tidak suka dugem (NOVA, 18 - 24 Oktober 2010)(So far, I did not like clubbing)

(9) Warga Jalan Niaga Pondok resah, menyusul maraknya penjualan miras oplosan di kawasan itu. (Posmetro Padang, 24 Juni 2013)(Residents of Jalan Niaga Pondok worried, because of the rise of miras sales in that region.)

(10) Technical Meeting dilaksanakan di ruang sidang khusus Disdikpora Sumbar (Padang Ekspress, 21 Juni 2011) (Technical Meeting held in a particular meeting room Disdikpora Sumbar)

(11) Tiga pelaku curanmor ditangkap (Padang Ekspress, 3 September 2013) (Three offenders of curanmor were arrested.)

(12) Pemerintah mulai membagikan raskin (Singgalang, 27 Juli 2013)(The government began to distribute raskin) 
The above examples show that blending tends to be created by taking the word element anywhere, just form a new word that is memorable and easy to remember by the listener. Blending can also be done without considering syllable or not syllables, but it is good to hear and a little bit strange to the ear to listen to it. The shift of the word formation of blending in Indonesian can be summarized as follows.

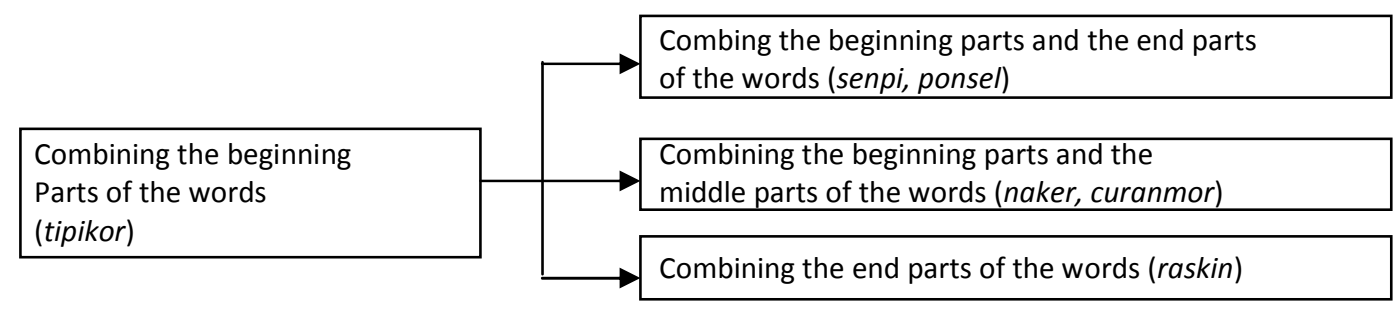

Figure 2: The shift of the Indonesian word formation of blending

Figure 2 above shows that there were shifts in word formation of blending, from only combining the beginning parts of words (e.g., tindak pidana korupsi becomes tipikor), into merging the beginning and end parts of words (e.g., senjata api becomes senpi, and telepon selular becomes ponsel). Then evolved into joining the beginning and middle parts of words (e.g., tenaga kerja becomes naker, and pencurian kendaraan bermotor becomes curanmor), then appears blending in the form of merging the end parts of words (for example, beras miskin becomes raskin).

\section{c. Clipping}

Clipping is a kind of word formation by cutting off part of a word. The cutting off part of a word can be the beginning part of a word, the end part of a word, as well as the beginning and the end part of a word.

(a) Clipping the beginning part of a word, e.g., kala (tatkala), laman (halaman),

(b) Clipping the end part of a word, e.g., pos (posisi), admin (administrasi), promo (promosi), perum (perumahan),.

(c) Clipping the beginning and the end of a word, e.g., lidik (penyelidikan)

Some examples of the clippings above can be found in the following sentences.

(13) Juventus mentas memakai sistem berbeda kala menghadapi Lazio (BOLA, 18-19 April 2013) (Juventus played using different system when facing Lazio)

(14) Lelang jabatan hanya berhenti pada pengisian orang baru untuk pos camat dan lurah (Republika, 12 Oktober2013)(Employment auction only stopped at fulfillment the new people to take position as subdistrict heads and village heads)

In the sentence (13), the word "kala" is a clipping from the origin of the word "tatkala." The beginning part of the word tat- was cut, leaving only the part of the word kala. Meanwhile, in the sentence (14), the word pos is a clipping from the word posisi.

Clipping forms on chatting media, SMS, and classified ads were more diverse, such as the removal of vowels in the word, the use of numbers instead of letters and words, and combination of letter/s and numbers. Take a look at the following examples.

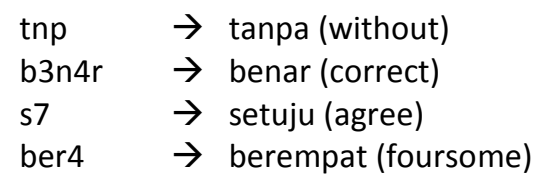


The examples above show that text communication like SMS on mobile phones and internet, and classified ads have changed the pattern of clipping in Indonesian.

Based on the above finding, it can be concluded that the shift of the Indonesian word formation of clipping can be expressed as follows.

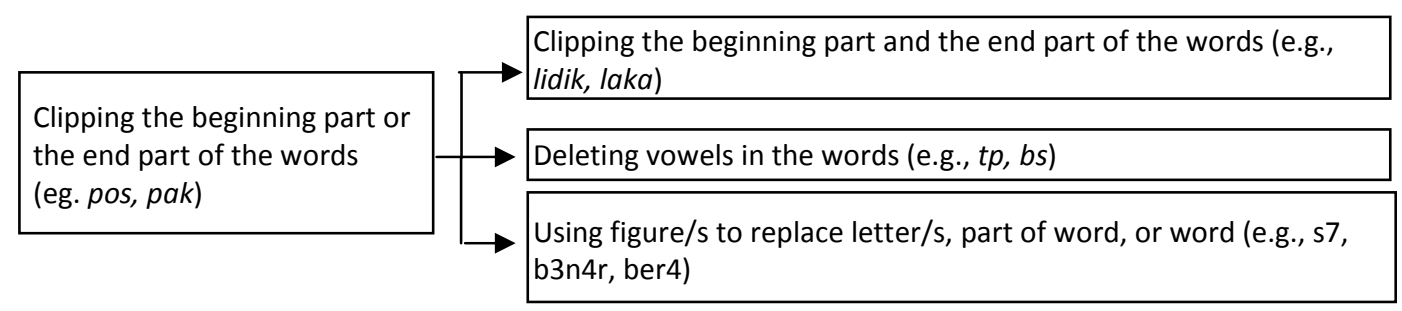

Figure 3: The shift of the Indonesian word formation of clipping

Figure 3 above shows that there were shifts in the Indonesian clipping formation from the earlier forms such as cutting the beginning or end of a word (for example, posisi became pos, and bapak became pak), turned into cutting the beginning and end of a word (for example, penyelidikan became lidik, and kecelakaan became laka), deleting vowels in the word (for example, tapi became tp, bisa became bs), and the use of figures to replace letters, parts of words, and words (for example, setuju bacame $s 7$, benar became $b 3 n 4 r$, berempat became ber4).

Combination of Acronyms and Blending or Clipping

Indonesian word formation can also be created by combining acronyms and blending. The combination can be done by placing the acronym at the beginning or the end of the derived words. Look at the sentence below.

(15) Penyidik satuan khusus JAM Pidsus Kejaksaan Agung melakukan pemeriksaan (Kompas, Juni 2014).

(Special unit investigators JAM Pidsus Attorney General did examination)

The word JAM Pidsus (Jaksa Agung Muda Pidana Khusus/Deputy Attorney General for Special Crimes) in the above sentence is a word formed by combining acronyms and blending. The early part of the word is an acronym (JAM), while the final part Pidsus word is blending (pid = pidana/criminal and sus $=$ khusus $/$ special). Look at other examples below.

$\begin{array}{lll}\text { Timnas PEPI } & \rightarrow & \text { Tim Nasional Peningkatan Ekspor dan Peningkatan Investasi } \\ & & \text { (National Team for Export and Investation Enhancement) } \\ \text { Timnas U-19 } & \rightarrow & \text { Tim Nasional Usia 19 (National Team of Age 19) } \\ \text { Ditjen Pas } & \rightarrow & \text { Direktorat Jenderal Pemasyarakatan (Directorate General of Social } \\ \text { Life) }\end{array}$

The first two examples above are the combination of acronyms and blendings, while the last example is the combination of blending and clipping.

\section{2) The sociolinguistic functions of acronyms, blendings, and clippings}

Sociolinguistic functions are the role played by a particular form of language within a speech community. In this study, we use the term to mean formal/informal interactions and functions carried out through the use of language or text message. 
The language of individual varies from a situation to another situation. At some occasions, people talk formally, and some other occasions they talked technically as well as formally. At some different events, they become informal yet technical and sometimes informal and nontechnical.

The use of acronym is dependent upon the context of communication since its meaning will be different if it is used in different context. It was found that acronyms have homophonic form such as found in the nonacronym word. For example in terms of education, BOS is the acronym of Bantuan Operasional Sekolah (School Operational Assistance), while in the automotive world BOS stands for Bursa Otomotif Seken (Second-hand Automotive Stock). In a nonacronym word, the word bos means employer or manager. In sociolinguistics, this phenomenon is called registers, special linguistic terms to be used in a particular situation. Register is a language variety according to use. It may be related to any specific situation or profession.

In the social and political world, the use of clipping, acronyms and blending for addressing someone became new trends beginning from the old era, new era, until reformation era in Indonesia. At the beginning of independence, community and political leaders tend to be invoked using clipping word (name) for addressing someone. For example, Sukarno was called "Bung Karno," Soetomo was called "Bung Tomo," and Suharto was called "Pak Harto." After the Reformation era, the calling name tends to use acronyms and blending. For example, SBY (Susilo Bambang Yudhoyono), JK (Jusuf Kala), and Jokowi (Joko Widodo). So, there is a shift in the use of acronym, blending, and clipping in social and politics in Indonesia.

Sociolinguistically, the use of clipping shows intimacy, the emotional closeness between the speakers and the listeners. Similarly, the blending forms that often arise in informal language, also appears in formal language. Blending frequently appears in the name of formal institutions such as Kemendikbud (kementerian pendidikan dan kebudayaan/ministry of education and culture), polantas (polisi lalu lintas/traffic police), and mensesneg (menteri sekretaris negara/Minister of State Secretary). Acronyms often appear in formal languages such as PBB (United Nations), APEC, and ASEAN. Acronyms are also used to indicate a suspect in a criminal case. So, they used dominantly in the formal conditions. A combination of blending and acronyms also appeared in naming institutions such as JAM Pidsus, and Kemenpan RB. From the above phenomena, it can be stated that the formation of new words in the form of acronyms, blendings, and clippings are influenced by the thinking process of the user language itself. The use of clipping shows emotional closeness between speakers and the one addressed. Acronyms show formality, while blending is in the middle, between formal and informal situations. Acronyms, blendings, and clippings are created to make communication becomes more effective and more efficient.

Abbreviation is created for practicality of communication. A long phrase that is difficult to capture in the overall intent can be delivered more practically and more communicatively by using abbreviation (acronyms, blendings, and clippings). Practicality, effectivity, and communicativeness of the use of the abbreviation will be felt when it has been trendy popular, such as ATM BCA, UU MD3, miras, sembako, narkoba, lidik, pos, and so on. These words have been felt as a word that has a direct reference with which it stands without going through an understanding of the stands. 


\section{3) The productivity of acronyms, blendings, and clipping}

Productivity in the Indonesian word formation of acronyms, blendings, and clippings will be divided into four types, namely (1) very productive, (2) quite productive, (3) less productive, (4) not-productive. The system of word formation is very productive if the process was very common on eligibility conditions, predictable, there is no obstacle; quite productive if the process was common in many types of conditions that meet qualifications, somewhat predictable, sometimes there are obstacles; less productive if the process only occurs in certain types of conditions with and often challenged; and not productive if the process occurs only in exceptional conditions, and is very limited. Productivity in Indonesian system of word formation based on morphological study was to determine what kind of word formations (acronyms, blendings, and clippings) are the most productive morphologically in the Indonesian system of word formation. Look at the following table.

Table 1: Productivity of the Indonesian abbreviation system of word formation

\begin{tabular}{|c|c|c|c|c|c|c|}
\hline \multirow[b]{2}{*}{ No } & \multirow[b]{2}{*}{$\begin{array}{l}\text { Types of Word } \\
\text { Formation }\end{array}$} & \multirow[b]{2}{*}{ System of Word Formation } & \multicolumn{4}{|c|}{ Level of Productivity } \\
\hline & & & $\begin{array}{c}\text { Very } \\
\text { Productive }\end{array}$ & $\begin{array}{c}\text { Quite } \\
\text { Productive }\end{array}$ & $\begin{array}{c}\text { Less } \\
\text { Productive }\end{array}$ & $\begin{array}{c}\text { Not } \\
\text { Productive }\end{array}$ \\
\hline \multirow{7}{*}{$\begin{array}{l}1 \\
.\end{array}$} & Acronyms & Initiation letters & $\mathrm{V}$ & & & \\
\hline & & Initiation letters and figures & & $\mathrm{V}$ & & \\
\hline & & Initiation using small letters & & & & $\mathrm{V}$ \\
\hline & & Compound acronyms & & & $\mathrm{V}$ & \\
\hline & & Pronouncing the letters & & & & $\mathrm{V}$ \\
\hline & & $\begin{array}{l}\text { Changing one letter with } \\
\text { corresponding sound }\end{array}$ & & & & $\mathrm{V}$ \\
\hline & & Borrowings & & $\mathrm{V}$ & & \\
\hline \multirow{6}{*}{$\begin{array}{l}2 \\
.\end{array}$} & Blendings & Beginning parts & $\mathrm{V}$ & & & \\
\hline & & Beginning part and end part & & $\mathrm{V}$ & & \\
\hline & & Beginning part and middle part & & $\mathrm{V}$ & & \\
\hline & & Middle part and end part & & V & & \\
\hline & & End parts & & V & & \\
\hline & & Borrowing & & & $\mathrm{V}$ & \\
\hline \multirow[t]{4}{*}{3} & Clipping & Beginning part or end part & & $\mathrm{V}$ & & \\
\hline & & Beginning and ending & & V & & \\
\hline & & Deleting vowels & & & $\mathrm{V}$ & \\
\hline & & $\begin{array}{l}\text { Using figures to replace letters } \\
\text { or words }\end{array}$ & & $\mathrm{V}$ & & \\
\hline \multirow{3}{*}{4} & Combination of & Acronym dan Blending & & $\mathrm{V}$ & & \\
\hline & acronyms \& & Blending and Clipping & & & & $\mathrm{V}$ \\
\hline & clippings & Borrowing & & & V & \\
\hline
\end{tabular}

The above table shows that of the four types of word formation; acronyms, blendings, clippings, and the combination of acronyms and clipping, blending formation are the forms that have the most variations. The most productive system of word formation is initiation acronym and blending of the beginning of the word. It was found that the most productive word formation system is the acronym and blending.

\section{Discussion}

The emergence of Indonesian new words through the process of abbreviation such as acronyms, blending, and clipping has given shade on the Indonesian word formation phenomena. The new phenomena that appear are the tendency to make abbreviation forms to become words that are easy to read and give a particular impression to the listener. These phenomena are the reflection of the influence of social and cultural changes that appear on their language behavior. Communities that used to abiding the 
rules tend to uprise against the constraints given so that their linguistic behavior came out of the existing predominance rule. Acronyms, blending, and clipping as the process of forming new words no longer follows the basic pattern that is standard but tends to give priority to create nice sound or pleasant to hear so that it is easily remembered by the listeners.

Sariah's study (2014) showed that many of the acronyms found were phonotactically unusual in Indonesian. This oddity appeared in the row of phonemes such as /tb/ on GATBI (Gabungan Toko Buku Indonesia/Indonesian Bookstore Association), and /pd/ on APDASI (Asosiasi Pedagang Daging Sapi Indonesia/ Indonesian Beef Traders Association). Unusual phoneme series were also found in blending, such as /mn/ on Kamnas (Keamanan Nasional/ National Security) and /kc/ on dokcil (dokter kecil/child doctor). Oddities were also found with the occurrence of two consonants together consecutively, both on acronyms and blending, such as $/ \mathrm{pp} /$ on APPMI (Asosiasi Pengusaha dan Perancang Mode Indonesia/ Indonesian Association of Fashion Designers and Entrepreneurs) and / $\mathrm{mm} /$ on Jamman (Jaringan Masyarakat Madani/ Independent Community Network). In blending, it was also found unusual appearance of consonants that cannot close Indonesia syllables such as /g/ on Karpeg (kartu pegawai/employee card), and /v/ on pemprov (Pemerintahan Provinsi/Provincial Government).

With the arbitrary nature of language, the emergence of new vocabulary is possible for all the time and can be done by anyone of the language speakers. The arbitrariness of language invites the creative speakers creating new terms, including acronyms, blendings, and clippings. This is usually begun with the fad of a speaker; then since it was pleasing to the ear and undewithr context of communication, the fad word was then used by other speakers. Finally, the new expression was dispersed and used by the group of people in conversation.

Zaim (2008 and 2009) in his article and paper on the Indonesian word formation found in newspapers claimed that the emergence of acronym in newspaper headlines are as communication efficiency efforts. New word formation not only appears in written language but also in the spoken language as found in the show on television and radio as well as in everyday conversation.

\section{CONCLUSION}

Based on the results of data analysis and research findings stated above, the results of this research can be summarized as follows. The system of acronym, blending, and clipping formation in Indonesian written language has shifted in determining the elements that should appear as a component in the acronym, blending, and clipping. The shifting systems of acronym, blending, and clipping formation occurred with the discovery of some variants of the standard system as stated in the standard Indonesian grammar books and the guidelines of Indonesian term formation. The shifting in acronyms occurred with the occurrence of figures that show the frequency of occurrence of the same sound, the acronym without the use of capital letters, pronouncing the letter of the acronymized element, and the emergence of compound acronym. The shift of blending occurred with the development of variants of the blended words (combining beginning, end, or middle of the word). The 
shift in clipping occurred in the emergence of variants of cutting parts of the omitted word (beginning, middle, or end).

The sociolinguistic function of acronym, blending, and clipping formation is an attempt to make effective communication. The use of abbreviated words referring to the specific terms is easier to understand and remember than the long words. The widespread use of acronym, blending, and clipping led to the emergence of the formation of the abbreviated words. Therefore, understanding the context of the speech and language registers allow us to understand the meaning of the acronym, blending, and clippings that appeared. The use of acronyms, blending, and clipping can also show formal and informal relationships between the user of the words in the language situation happened.

The productivity of the Indonesian word formation systems was found on acronyms and blending. The productive acronyms were in the form of initiation of the beginning letters of the word, and in blending is blending the beginning of the word, while clipping can be categorized quite productive in the Indonesian written language.

\section{REFERENCES}

Alwi, H. (1998). Tata bahasa baku bahasa Indonesia (Edisi Ketiga). Jakarta: Balai Pustaka.

Aronoff, M dan Ress-Miller, J. (2001). The handbook of linguistics. Oxford: Blackwell Publishers Inc.

Booij, G. (2007). The grammar of words; An introduction to morphology. Oxford: Oxford University Press

Katamba, F. (1993). Morphology. London: Macmillan Press Ltd.

Kridalaksana, H. (1983). Kamus linguistik. Jakarta: PT Gramedia

Kridalaksana, H. (1990). Kelas kata dalam bahasa Indonesia. Jakarta: PT Gramedia

Lieber, R. (2009). Introducing morphology. Cambridge: Cambridge University Press

Mahsun. (2005). Metode penelitian bahasa. Jakarta: Raja Grafindo Persada.

McManis, C. (1987). Language files: Materials for an introduction to language. Ohio: Advocate Publishing Group.

Moeliono, A.M. (1988). Tata bahasa baku bahasa Indonesia. Jakarta: Departemen Pendidikan dan Kebudayaan

Pusat Bahasa (2004). Pedoman umum ejaan bahasa Indonesia yang disempurnakan. Jakarta: Pusat Bahasa, Departemen Pendidikan Nasional

Pusat Bahasa (2007). Pedoman umum pembentukan istilah. Jakarta: Pusat Bahasa, Departemen Pendidikan Nasional

Sariah (2014). Akronim yang berfonotaktik tidak lazim dalam bahasa Indonesia. Linguistik Indonesia: Jurnal IImiah Masyarakat Linguistik Indonesia, Vol 32 No. 1: 47-62 
M. Zaim - Shifting the system

Sudaryanto. (1993). Metode dan aneka teknik analisis bahasa: Pengantar penelitian wahana kebudayaan secara linguistis. Yogyakarta: Duta Wacana University Press.

Sugono, D. (2009). Pengindonesiaan kata dan ungkapan asing. Jakarta: Pusat Bahasa, Departemen Pendidikan Nasional

Sumarsono and Partana, P. (2002). Sosiolinguistik. Yogyakarta: Sabda

Sutawijaya, H.A. (1996). Morfologi bahasa Indonesia. Jakarta: Departemen Pendidikan dan Kebudayaan

Trosborg, A. (1997). Text typology: Register, genre and text type. Text Typology and Translation, 3-23 (ed: Anna Trosborg), John Benjamins Publishing Company.

Trudgill, P. (1992). Introducing language and society. London: Penguin

Wardhaugh, R. (1986). Introduction to sociolinguistics ( $2^{\text {nd }}$ ed.). Cambridge: Blackwell

Zaim, M. (2000). Pembentukan kata dalam bahasa Indonesia. Makalah Seminar Linguistik MLI Unand, 11 Mei 2000.

Zaim, M. (2001). Pembentukan kata dengan akronim, singkatan dan penggalan dalam bahasa Indonesia mutakhir. Humanus, Vol. IV, No. 1 Tahun 2001: 10-21

Zaim, M. (2008). Pergeseran sistem pembentukan kata bahasa Indonesia pasca Orde Baru. Laporan hasil penelitian. Jakarta: Depdiknas

Zaim, M. (2009). English morphology. Padang: FBS UNP Press

Zaim, M. (2014). Metode penelitian bahasa: Pendekatan struktural. Padang: FBS UNP Press 